\title{
And Zaccheus remained in the tree: Reconciliation and justice and the Truth and Reconciliation Commission
}

A Boesak

(University of Stellenbosch)

\section{ABSTRACT}

\section{And Zaccheus remained in the tree: Reconciliation and Justice and the Truth and Reconciliation Commission}

South Africa's Truth and Reconciliation Commission (TRC) has been praised the world over for its work and its example is being followed by many countries, in Africa especially. In South Africa the TRC has raised hopes and expectations that went beyond the TRC's functionality within the framework of South Africa's political settlement and its legal mandate given by Parliament. This contribution argues that there is growing disillusionment with the work of the TRC especially among black communities and that one of the major flaws of the TRC rests in its failure to link reconciliation with justice. Justice here must not be understood within the strict legal terms that some have applied to the work of the TRC but rather from within the expectations created by the TRC itself through its own insistence that its work should be seen as a Christian endeavour. This failure has a direct bearing on the situation South Africa finds itself in today, and the author argues that a return to an understanding of reconciliation that presupposes justice will help address one of the most critical issues in our social, political and theological discourse today.

\section{INTRODUCTION}

The work done by South Africa's Truth and Reconciliation Commission in which Piet Meiring played such a significant part, remains entirely relevant, not just for South Africa, but for many places around the world as one can see from the passionate debates rekindled by the death of Chile's erstwhile dictator, General Pinochet, and the continuing tragedy in the Middle East as well as the painful search for reconciliation in Rwanda and more recently, Liberia. It is not entirely cynical to say that "reconciliation and forgiveness" has become a growth industry.

South Africa's Truth and Reconciliation Commission's work has left a huge legacy, and South Africa and the world is still in the process of evaluating it. I think it is fair to say that its success is 
mainly reflected in the fact that we have been able to create a platform to break the silence around all those unspeakable things that happened during the reign of Apartheid, giving some victims to some extent the opportunity to speak out and bare their souls to a nation that by and large was willing to listen. It is true, as some were quick to point out, that in fact very little of the truth about human rights abuses actually did come out (Bell \& Ntsebeza 2001), but nonetheless enough of that truth was heard to dispel all illusions about the horrific nature of the beast we were saddled with for so long.

Furthermore, it did create a context for the hard work of political accommodation, the breaking down of barriers and the building of pockets of trust which otherwise would have been almost impossible to achieve. Whatever the difficulties we may now face, and these are both legion and profound, the foundations for nation building laid down in the work of the Commission are infinitely better than if the expectations of violence and mayhem would have been fulfilled.

Ten years of grappling with these issues have raised a host of theological questions as fundamental as they are unavoidable, and I am not sure just how ready we are to recognise and face them. I raise some of them now not for the purposes of discussion here, but to highlight the complexities we are challenged with:

- $\quad$ Just how wise was the link between the legal and political process of truth seeking and the demand for reconciliation?

- Is the establishment of the "truth" as required by law written especially for the TRC process, adequate in terms of the truth demanded by reconciliation, and do the discrepancies not create problems the TRC process could not possibly handle?

- Is it always necessary to know all the truth for the sake of reconciliation, and once known, will it not jeopardise rather than facilitate reconciliation?

- Is a Christian understanding of reconciliation (which in South Africa's case was perhaps unavoidable) helpful in both the process and its outcomes, especially in light of the ongoing doctrinal debates on the atonement, and the conflicting 
interpretations of the New Testament on this subject within Christian theology? (Wiersinga, 1971).

- $\quad$ Furthermore, can, as Archbishop Tutu seems to have done more than once, the idea of Jesus' sacrifice on the cross "for our salvation" be directly applied to our sacrifices in the struggle in order to achieve a greater good, namely the salvation of the nation?

- What if the consequences of the discovery that the doctrinal ideas of reconciliation as the satisfaction of a wrathful God's justice are such a huge impediment to what South Africa desperately needed, that they have to either be discarded, or ignored, or suppressed, or made uniquely applicable only in church. That for society, however, they seem to have no practical value? Can Christians live with a dichotomy of such enormous proportions?

- $\quad$ Thirty years ago we insisted that the legitimacy of the African context required of us a fundamental re-reading of both our context and the Scriptures, a new hermeneutic and a different interpretation. The continuing development of the African context is now more consciously linked to the redefinition of an African Christian identity; atonement and reconciliation as an act of sacrificial, transformational love, rather than an act of wrathful justice; the cross not just as locus of what God has done, but understanding that the way of the cross we are called to follow in order to participate in God's work of reconciliation and redemption in Christ, is what our context calls for. Jesus' sacrificial servanthood, his willingness to suffer for the sake of others, the inclusiveness of his embrace, this is the way we have come to understand his vicarious sacrifice and the expiation of our sins. This is what has made us respond to God's merciful forgiveness and God's reconciling work in Christ. Is that a fundamental departure from, and an invalidation of, our inherited doctrinal traditions?

If these few questions have not the value of enlightenment, at least they help us to understand that in this present discussion we are merely scratching the surface. 


\section{WHY DID ZACCHEUS NOT TESTIFY?}

It is my distinct impression that South Africans in general have expected more of the process of reconciliation. Everywhere there are signs of uneasy discontent. We know that we know more about the truth that still lies buried than the "truth" that has been allowed to be heard. F W De Klerk's successful court action to block publication of certain documents and his offensive "let-bygones-be-bygones" rhetoric, the angry response of the ANC to certain aspects of the TRC process, the baleful resistance of a Mangosuthu Buthelezi or a P W Botha who has gone to his grave unrepentant and unreconciled with most of the country, the failure of the TRC to bring to book those who should have taken political responsibility for Apartheid: the political leaders, the generals, big business. There is deep anger at the government's inability to bring some dignity to the process of compensation of victims and at the fact that too many "got away with it”. Mamphela Ramphele's sober (and disillusioned?) assessment speaks for a growing number of South Africans when she speaks of "the miracle that never was" (Ramphele 2008:46-69).

In the daily battles with high levels of crime, poverty, corruption and HIV/AIDS, the deep-seated evils of racism, and a waning trust in government's commitment to the basic tenets of democracy, faith in reconciliation and that anything would come of it, is whittled away. There is cynicism also at the world's persistence that South Africa is a "model of reconciliation". South Africans know better even though we continue to speak hopefully, if sometimes naively, of the "rainbow nation". Nonetheless, the hard questions are being asked. "Was truth and justice sacrificed to reconciliation?" ask Bell and Nstebeza (2001:1), and further, "One is entitled to ask how long South Africa's 'political miracle' will last”. (Bell and Nstebeza 2001:3)

Archbishop Tutu himself put it more graphically than anyone else when he spoke of people's frustration and anger at an incomplete reconciliation process "ten years after freedom", but still living in squalor while others "mostly white", live in "palatial homes”. "I don't know”, Tutu exclaimed, "why those people don't just say, "To hell with peace. To hell with Tutu and the Truth Commission" (Ramphele 2008:66). In other words, in the matter of reconciliation, Desmond Tutu is echoing the suspicion of many that 
this time, Zaccheus was ignored. Jesus may have seen him, but the TRC did not.

I point to the story of Zaccheus in Luke 19:1-10 because this wonderful, multi-layered story has such radical consequences for reconciliation. The story is about the town's rich, infamous tax collector whose wealth had been built through his clever but corrupt manipulation of the tax system and the exploitation of both opportunities and people that went with it. It is logical that it might have been the rich who resented him most, but it is the poor that suffered most from the corrupt and ruthless practices of Zaccheus and his subcontractors. No prizes for guessing at the tensions between the community and this man "of short stature".

Aware of his physical impediment and probably knowing that he would get no sympathetic preferential treatment from the crowd, he climbs up the tree in hopes of seeing Jesus. Then we have Jesus stopping right at the spot, looking up, the whole crowd fading into fuzzy irrelevance as the focus is entirely on the little man in the sycamore tree, the conversation with Jesus, his conversion and his reaction. He draws radical conclusions for his life from his encounter with Jesus and the act of being reconciled with God. He knows this reconciliation needs to be affected with the community in order for it to be genuine. He understands that reconciliation has to be transformation if it is to mean anything: of his life, his life style, his relationships with the community and especially with those he has wronged. Reconciliation means the restoration of justice.

So Zaccheus sets out to do just that. He does not spare himself or his possessions. He acknowledges that his wealth was ill-gained, stolen from the sweat of the poor. For him reconciliation is not cheap: "Look, half of my possessions Lord, I will give to the poor; and if I have defrauded anyone of anything, I will pay back four times as much". Like David, Zaccheus does not want to bring a sacrifice "that costs me nothing" (1 Chron 21:24).

And because Jesus, the incarnation of the reconciliation and compassionate justice of God, understands how crucial a thing Zaccheus is doing, He does not enter into some meaningless moralising chat about the relative worth or worthlessness of money, or how just love is enough. Jesus is just as radical, linking Zaccheus's response immediately to his salvation: “Today salvation has come to this house...”. And since there are crucial lessons to be 
dawn from this, the crowd is brought back into the conversation. “... because he too is a son of Abraham" (vs 9)

What intrigues here are the radical consequences of genuine reconciliation: transformation, restoration, justice. Herein was the greatest challenge for the TRC, and here is where it stumbled. Zaccheus was never called to testify. As far as the TRC was concerned, Zaccheus, with his radical understanding of reconciliation, remained in the tree.

But we have been warned. Early on Ibbo Mandaza of Zimbabwe had pointed to what he considered to have been one of the main problems in Zimbabwe: the requirement to succumb to what he called the "ideology of reconciliation" (Mandaza 1999:86, 87). He warned South Africa not to ignore political and economic realities for the sake of political acceptance in the international community. And Mahmood Mandani, like others of us, expressed concern that South Africans continued to speak in terms of "victims" and "perpetrators" of Apartheid (Mamdani 1996). The focus is too narrow, he argues. There are some whites who perpetrated the system of Apartheid, but all whites benefited from it. This is how we should address the question of guilt, repentance, reparations and restitution. He was right. We focused on what he called "the fractured elite" (perpetrators and victims) instead of on society as a whole, on individuals instead of on the systems of injustice that Apartheid essentially was, so that justice never became a demand for systemic reform of society as a whole. We did not seem to get beyond the single perpetrator or the single victim.

This narrow emphasis spawned a further injustice. It created the impression that Afrikaans speaking whites, the most active "perpetrators" of Apartheid, were the only guilty ones. English speaking whites, who benefited hugely from colonialism and Apartheid, both denied, and escaped all blame. Generally speaking, English speaking South Africans' arrogant denial of their guilt in this matter remains one of the most stubborn stumbling blocks to genuine reconciliation in South Africa today.

Of course, these very questions, guilt, remorse, repentance, forgiveness, restitution are all intrinsic to the issue of reconciliation as understood by Christians. But through all of the TRC process the churches have remained strangely quiet, speaking vaguely of peace and rather naively of a Christian understanding of an "ethic of 
ubuntu", but never actively entering the fray, never challenging the dominant discourse, never fighting for either the biblical understanding of reconciliation or for the rights of the vulnerable, the weak and the poor as a consequence of it. We did not, forthrightly, boldly and honestly confront the politicians with the truth that one cannot use the concept of reconciliation as a political subterfuge without understanding, and honouring the biblical demands that inevitably come with it. So now everywhere there are signs that our efforts towards reconciliation are foundering.

For me personally, as for many others who take reconciliation seriously, the moments of genuine remorse and repentance that did occur, followed by genuine forgiveness on a very personal level, though rare, were priceless. These moments represent that crucial spiritual element without which reconciliation is not possible and without which pure political accommodation remains a singularly insecure foundation for our common future (Meiring 2000; De Gruchy 2002). But despite this, and despite our gratitude for the work of the TRC, we have to admit that there have been major failures. I offer a broader argument elsewhere (Boesak 2005:171203). Let me however, here point out some issues and at the same time focus our discussion on the matter which is seizing us here: reconciliation and justice.

At the outset, the ANC government had set for itself the goals of "reconciliation, reconstruction and development" (De Lange 2000:14-31). These, the "kernel of the social transformation project" could be reached by the "attainment of the twin goals of socioeconomic justice and the restoration of moral order in our society". This is according to Johnny de Lange, currently Deputy Minister of Justice in the South African Cabinet. The government regards our TRC as "unique" because the aim was to achieve both justice and reconciliation, not just one or the other. Justice is referred to in the "broadest sense", as "collective justice, social justice, a restorative justice... aimed at nation building and reconciliation", that focuses on the future rather than on the past, on understanding rather than vengeance, on reparation rather than retaliation, on ubuntu rather than victimisation. De Lange rejoices in our success, because we have moved "beyond" punishment and justice is not only done, it is "seen to be done". It is restorative justice, but also contains essential elements of retributive justice in that the truth is told, lies are exposed and the perpetrators are becoming known. It may not be 
perfect justice, de Lange concedes, but then perfect justice does not exist, and "compromises have to be made for the greater good." All this is to achieve an even greater goal, namely "to heal our nation, to restore the faith of those in our country and the international community in our common future".

For our limited purposes, I shall briefly approach the issue of justice from three points of view. First, I shall speak of justice as the restoration of integrity; second, of justice as the restoration of human dignity; and third, of justice as the restoration of human contentment. The restoration I speak of is not a historical restoration of situations before the ravages of colonialism and Apartheid. I speak of the restoration of the intentions of Yahweh as they are spelt out in the announcements of the prophets, in the longing of the songwriters of the Old Testament, and in the life and work of Jesus of Nazareth.

\section{JUSTICE AS THE RESTORATION OF INTEGRITY}

Even taking into account de Lange's natural propensities as a lawyer and a politician, one must consider his understanding of justice to be far too narrow, especially as he wishes to place it within the context of reconciliation. De Lange goes even further, adding these majestic words to his exposition: "Our call for a truth commission did not come from the Constitution or any law, but from our morality as people who want to heal our nation, and restore the faith of those in our country and in the international community in our common future" (De Lange 2000:18). This language is common, and spells out the abiding dilemma of South Africa's politicians. They strive furiously to define our political developments as a secular process, as matters of law and the constitution, the demands of Realpolitik and the vagaries of globalisation. But they cannot escape the intrusion of morality, the appeal to conscience, and the presence of spirituality, which are such inalienable elements of South African politics. This apart from the fact that they themselves have chosen for the link between our political processes, nation-building and socio-economic development with reconciliation, that unrelenting, demanding evangelical reality which bears no evasion. They are beginning to discover that wearing the mantle of a "rainbow nation" is not easy. Making reconciliation the centerpiece of one's "social transformation project" as the ANC claims, means taking up a cross one must bear to the end. If done with integrity and honestly, it 
becomes a light burden and an easy yoke. If it is just one more political subterfuge, it leads to all sorts of calvaries one cannot even begin to imagine. But this point, interesting though it may be, cannot be discussed here. We have to return to the business at hand.

De Lange's, and the government's, dilemma is that even in their narrow definition, justice has not been done, or seen to be done. Their intentions were that the perpetrators of human rights abuses be exposed, and if they willingly told the truth, they would be given amnesty. The victims will have the satisfaction of "having heard the truth" and of "reparations" by the government. Those perpetrators who did not disclose the full truth or did not come forward would be prosecuted through the "normal" channels of the law. De Lange was counting on the integrity not just of the TRC process, but of the justice system as well. By the same token, he was also counting on the integrity of the "perpetrators".

The fact is that the number of perpetrators who came forward were relatively small. The justice system did not offer much hope for justice as seen in the failed trials of Magnus Malan, Minister of Defence under P W Botha, and the apartheid scientist Dr Wouter Basson. They both refused to apply for amnesty and their trial costs were borne by the state. De Lange complained that the legal system "at the time" suffered from a "serious crisis of credibility, legitimacy and efficacy", and subsequently, "competent, honest, professional investigations and prosecutions could hardly have been expected" (De Lange 2000:29).

The problem is that the trial of Basson took place six years into the new democracy and the government had to face the same realities regarding the legal system even then. The new minister for justice, Bridget Mabandla, at her first public appearance, bemoaned the "untransformed nature" of the justice system and today there is open tension between the government and the courts because of the efforts at "transformation". The point is, de Lange's "imperfect justice" is still around, and he is not the one who is paying the price. The government's handling of the matter of reparations is nothing short of scandalous and the insult inflicted upon the victims of human rights abuses does not inspire trust in the integrity of our systems (Ramphele 2008:64-67).

The issue of accountability is a problem South Africans all know about, but find hard to address. Those who were called to 
account for their misdeeds were mostly the foot soldiers, ordinary security policemen and soldiers who carried out orders and who were told that they should do what they did "for the sake of God and for their country". But the generals, of the police as well as the armed forces, the scientists and the technicians of Apartheid, the politicians who made final decisions, were all left aside. That whole episode left an unhealthy odour hanging in the air.

We are also left to wonder about the "truth" we have heard. Journalist Terry Bell and Advocate Dumisa Ntsebeza (2001) present a strong case on this particular issue. The question is not only how much truth was eventually told, but even more pertinent, how much truth survived to be told. "In little more than six months in 1993", they tell us, "...some 44 metric tons of records from the headquarters of the National Intelligence Service alone were destroyed" - that is, shredded, wiped and incinerated, leading them to speak of "the paper Auschwitz" (Bell and Ntsebeza 2001:7). They conclude that "the undeniable reality is that many of the principal perpetrators of Apartheid were never called to account, but all too often remain in positions of power" (Bell and Ntsebeza 2001:1-3). For reasons not altogether pure, the government has decided to prosecute Apartheid Police Minister Adriaan Vlok and three others for the attempted murder of Rev Frank Chikane, and a plea bargain has ostensibly ended the matter.

The unexpected and courageous act of remorse and confession towards Chikane, one time Secretary-General of the South African Council of Churches by former Police Minister Adriaan Vlok, and his forgiveness by Chikane has shone an entirely new light on reconciliation in South Africa. It occurred completely outside the official process. It may not have completely turned the tide by itself, but it has set a benchmark for integrity and genuine reconciliation that the country has not experienced from senior politicians and it now leaves them exposed, if not ashamed. It is also a singular testimony to the power of the Holy Spirit in the life of a person and an example of genuine reconciliation inspired by the example of Christ. I therefore cannot see how his late prosecution could in any way serve the process of genuine reconciliation, and even the "deal" that was made to avoid further political embarrassment is itself in fact embarrassing. 
In line with this problem is the fact that significant sectors who in their own way represented the full weight of Apartheid injustices were not called to account either, or were called and simply refused to cooperate. I am thinking of the media, government agencies, the judiciary. The distressing rows around racism on the Bench, with accusations not coming from the general public but from judges, prove the reach of the consequences of such lapses.

If justice is the restoration of integrity, South Africa is suffering from that failure, and it is mostly the weak, the poor and the vulnerable who are paying the price.

\section{JUSTICE AS THE RESTORATION OF HUMAN DIGNITY}

"No Future Without Forgiveness" is the title of Archbishop Tutu's well known book (Tutu 1999). It expresses his firmly-held belief and conviction. He calls it a "gospel imperative" Christians cannot seek to avoid. At those amnesty hearings of the TRC Tutu insisted that "the victims of injustice and oppression must ever be ready to forgive". The Archbishop has exerted his authority and the stamp of a Christian understanding of reconciliation was firmly impressed on the TRC proceedings. Whether that was right is not the issue. It happened.

Many were unhappy about this. They claim that victims of Apartheid human rights abuses were placed in an atmosphere where the strong impression was given that forgiveness was the only acceptable response. The hearings were structured in such a way, said one witness, that any expression of a desire for revenge would seem out of place. "Virtues of forgiveness and reconciliation were so loudly applauded that emotions of revenge, hatred and bitterness were rendered unacceptable, an ugly intrusion on a peaceful, healing process." Philip Wilson, who attended the hearings, took this to be a kind of emotional blackmail (Graybill 2002:50).

Even worse, Audrey Chapman, another interested observer, has charged that at the Human Rights Violations hearings over which Tutu presided, more emphasis was placed on eliciting forgiveness from the victims than in securing knowledge of wrongdoing from the perpetrators (Graybill 2002:50). Under these circumstances there is hardly any possibility for the restoration of human dignity. Once again justice has been denied. The TRC did not succeed in creating a context in which the perpetrators of human rights abuses ever felt the 
need to show genuine remorse and repentance in response to the offer of forgiveness from their victims. And there are distressing examples of policemen acting out remorse and then joking about it in the crudest terms to journalists immediately outside the room (Graybill 2002:52).

Now I know the argument here is that the legal brief of the TRC did not require remorse, confession or repentance from such perpetrators. It only required telling the truth about an incident. But then it remains extraordinary just how much pressure was put on the victims to forgive, even if forgiveness was not asked for, or human speaking, not possible. But then, why call it "reconciliation"? We have not begun to consider the damage that was done, layered upon the pain of the past in addition to the pain of retelling without hope of any resolution, closure, restitution or restoration. In this regard a young woman is quoted as saying, "I don't know if I will ever be able to forgive. I carry this ball of anger within me and I don't know where to begin dealing with it. The oppression (of Apartheid) was bad, but what is much worse, what makes me even angrier, is that they are trying to dictate my forgiveness" (Verwoerd 1998). I think this is unforgivable.

Forgiveness is indeed a "gospel imperative" as Desmond Tutu says. But forgiveness is a willing response as an expression of our obedience to the prayer of Jesus that we should forgive "as our heavenly Parent has forgiven us". Forgiveness is always freely given. If it is given as response to a confession which itself is a plea and need for forgiveness, that is already remarkable enough. If it is given where the perpetrator sees nothing that he or she should be forgiven for, and there is no remorse or confession, it is extraordinary and an even greater cause for thanksgiving. But it can never be forced on anyone. No one should be coerced into forgiving, however subtle. Forgiveness is in itself an act of such sensitivity, such sacrificial self-giving, such enormous love that any attempt to coax it out of people robs it of its intrinsic value. It can never be taken for granted and is always the prerogative of the victim. Clearly most human beings need help to come to that point. But there is a vast difference between help and subtle pressure, especially in public, especially on national television.

There is a place for rightful anger, and the Commission should have given it that place. It is impossible not to be angry at what 
happened to people under Apartheid and it is grossly unfair to act as if that anger is an offence to God. That anger must not be denied, managed or manipulated. It must be given respectful hearing. Just as the victim has to hear the truth and the words of contrition, it is necessary for the perpetrator to hear the words of anger. The perpetrator has to see and hear the consequences of the wrongful deed in order to understand the depth of the wrong that was done, as well as the depth of the forgiveness given.

The miracle of God's grace is not that we manipulate the anger of the young woman into forgiving by making her feel guilty about her anger, but rather that she is moved to overcome her anger, to willingly forgive, and as she remembers what has been done to her, she thinks back not in hatred or bitterness or despair, but in gratitude of having been able to reclaim her humanity and in the process that of her torturer also, in order to create both a new humanity and a new beginning for both of them. Inasmuch as the TRC has denied people this, it has denied its own mission. It has subjected the victims of Apartheid to the pain and humiliation of "story telling" and has victimised them again in that they were denied the freedom of righteous anger and in the process to challenge the perpetrator on the basis of equality. Within the context of Apartheid and its aftermath, it is the expression of anger that brings the first level of equality, which then frees us for the equality of love. Only in the freedom of rightful anger can one find the freedom for that anger to be overcome, which in turn can lead to the freedom of forgiveness and the joyful liberation of the way of reconciliation.

In not being nearly as insistent with the perpetrators and beneficiaries of Apartheid as with the victims on this point, the TRC perpetuated the powerlessness of the victims because it exploited both their faith and their powerlessness to exact remorse. The same was not done with the powerful. They were both too powerful and too protected by the institutions of power: Parliament, the courts, the media, government. The same is true for the powerful institutions themselves. The TRC chose to make the radical (Christian) interpretation of reconciliation the litmus test for the victims, especially those who are Christians. Inasmuch as the TRC failed to apply that test universally, it failed both the victims and the gospel.

There are issues we shall only be able to mention but have no time to discuss, vastly painful areas the TRC was not able or willing 
to cover and which are virtually ignored in the discussions on reconciliation, perhaps partly explained by our pathological need "to move on". It is one thing to forgive the enemy, even though that is hard enough. But how does one forgive betrayal by one of your own, the security policemen, the informers, the torturers who lived in those communities? Blacks have been asked to forgive white people who gave the orders, and the whites who benefited from their deeds. But what about the restoration of those black communities? Truly awful things have happened there. There have been moving acts of reconciliation between blacks and whites, but hardly any between blacks who in the struggle stood on either side of the political divide. I fear that we have hardly scratched the surface.

It is time to speak about the third aspect of justice as I see it.

\section{JUSTICE AS THE RESTORATION OF HUMAN CONTENTMENT}

I have borrowed the phrase "human contentment" from John Calvin's sermon on Deuteronomy 24. It is a sermon that epitomises the radical Calvinism I have come to admire and embrace. It is about poverty and justice, about the rights of the poor, the quality and meaning of labour and the quality of community. In the question of economic justice, it is not just personal satisfaction that counts. It is the systemic transformation which extends justice to the other that helps society to function better. Calvin radicalises the notion of the "neighbour" to undermine selfish economic tendencies as well as uncaring politics. And then comes the sentence that shifts not only the paradigm of fighting poverty, but also dramatically the measure of our success in fighting poverty: "It is not enough to know that the poor person has work or receives charity, it is necessary to know if the poor person is content" (Calvin, Sermon CXL on Deuteronomy 24).

In de-linking reconciliation and justice, the TRC, and the whole reconciliation process, has completely missed this crucial point. And this is what we mean when we apply it to the political and socio-economic ramifications of reconciliation as we understand it. It is not when government or big business, or the media moguls are satisfied that justice has been done and that reconciliation "works". It is when the poor, the wounded, the vulnerable, are content. To be content is to be fulfilled, in body and spirit. It is when the fulfilment of one's human potential is taken seriously, when one is allowed to 
flourish, when one's rights are recognised, honoured, respected and upheld.

The TRC has taken issue with the government on the question of reparations for the victims of human rights abuses. The sum of around R25000 (\$4000) which the government finally seems to have agreed to has hardly enhanced the dignity of the victims, the process or, for that matter, the government itself. But the issue goes somewhat deeper. The TRC failed to make big business accountable for their part in the creation and maintenance of Apartheid. It did not see, and did not take up the challenge of the causative role played by the systems of white political dominance, racial capitalism and Apartheid over a considerable period of time. It did not, argues economist and historian Sampie Terreblanche, "face the problem of those systems, in a deliberate and systemic way, bringing about and sustaining white wealth and white privileges on the one hand, and black poverty, black deprivation and black humiliation on the other" (Terreblanche 2001:273-276). In short, it let big business off the hook.

This presented us with a second problem in this regard. The TRC, failing to call big business properly to account, retreated to the shifting sands of charity, appealing to the business community to voluntarily compensate black people for their suffering under Apartheid. The exploitation of blacks did not happen voluntarily. It was compulsory and systemic. It was based, Terreblanche reminds us, on an economic and political system embedded in a network of compulsory legislation and justified by ideologies that were propagated as self-evident truths. To expect that big business would be prepared to compensate, and to the necessary degree, for the injustices committed for almost a century is not only totally idealistic but also hopelessly naive. And in truth, the issue here is not charity, but economic justice, and it is a tragedy that the TRC did not see, or insist upon the relationship between reconciliation and socioeconomic justice.

The socio-economic injustices that plague our society are symptoms of the deeper malady that ails us: we are far from the reconciled society we claim to be. Those who disagree argue that South Africa is already experiencing a "rapid deracialisation of capital". But that is patently not true. The most recent studies show an alarming growth in the levels of poverty, and the gap between 
rich and poor in South Africa is widening, as is the gap between the wealthy, new, black elite and the poor masses. A recent study by Eighty20, a South African think tank, reveals that up to $60 \%$ of the population has to survive on less than $\$ 3$ per day, while not less than $15 \%$ are trying to make a living from less than $\$ 1$ a day. This is utterly shocking.

In 2003, Black Economic Empowerment deals amounted to over $\$ 7$ billion. But that staggering amount was divided amongst basically the wealthiest and most powerful six BEE groups in the country. That is not "deracialisation of capital" at all. That is pure myth-making. All it means is that the tight circle of the new, empowered black elite have joined the white rich and powerful and the rich are still getting richer.

There is also growing evidence that per capita income growth will diminish as a result of increasing dependency ratios, increased burdens on health systems, constrained investment in productivity and reduced labour forces, because of, among other things, the impact of AIDS. In South Africa, the rate of AIDS infections has gone up to almost 5 million in total now, and AIDS deaths have now reach the staggering total of 900 per day with almost 200 of those children.

All the talk of reconciliation, all the slogans about the rainbow nation, shall remain empty unless reconciliation means compassionate justice done to these, the least of the family of Jesus.

\section{RECONCILIATION, LOVE AND COMPASSIONATE JUSTICE}

“A just and well-regulated government”, said John Calvin in a sermon on Psalm 82:3, "will be distinguished for maintaining the rights of the poor and afflicted." What is required is not charity that would leave systemic injustices untouched. Calvin is not impressed with superficial morality or political piety of either the wealthy or those in positions of political power. And neither should we. We cannot be satisfied with programmes and slogans that keep the poor chanting and dancing but leave them hungry. The measure for good governance is not how we please the G8, but our conduct towards the poor. In other words, conduct measured by political and economic policies that guarantee justice and are driven by compassion. And it begins by recognising the rights of the poor. 
A social situation is just, argues Nicholas Wolterstorff, when the rights of people in that situation are honoured. He speaks of rights as "ground requirements". These rights are not only grounded in justice and in the love of God, they mean also that "we are not beggars in life" (Wolterstorff 1999:107-130). Put differently, it is the right of the poor not to be beggars in life, not to be poor, but to be content. Reconciliation is about confession and confrontation with evil; it is about conversion and forgiveness; it is about personal and societal transformation; it is about restitution, restoration and compassionate justice.

There are those who fervently disagree, from politicians like Thabo Mbeki to theologians like Charles Villa-Vicencio. For them, reconciliation in South Africa should be seen as political, a purely secular process of the accommodation of socio-political and historically determined realities. They think all talk of the "neighbour", of rights and compassionate justice is "romanticising", "excessive spiritualisation”, asking "too much”, and hence creating expectations that in the real world cannot be fulfilled. Academic Jakes Gerwel even speaks of such ideas as "pathologising the nation". We are, in other words, "chasing rainbows" (Gerwel 2001:277-286).

It all depends where one stands. And in the black Reformed tradition in South Africa we have formulated this in the Confession of Belhar, the confession adopted as a fourth standard by the then Dutch Reformed Mission Church (now the Uniting Reformed Church in Southern Africa). In Article Four Belhar proclaims God as "the One who brings justice and true peace, and that in a world filled with injustice and enmity God in a special way is the God of the destitute, the poor and the wronged... That the church as possession of God is called to stand where God stands, namely against injustice and with the wronged". It is a confession out of the African context that has reshaped our expression of faith and infused us with a new spirituality without which, we know now, the church would not have survived.

As South Africa's transition unfolds, it continues to show us not only how far we have come, but also how much we have still to do. Our work towards genuine reconciliation has just begun, and by divine irony it is revealed in both the continuing systemic distortions, the unending cries of the poor and the conversion of 
Adriaan Vlok. A new door for genuine reconciliation has been opened. We have an opportunity to do it right. And if we do this, our horizons established by the kingdom of God, our strength renewed by the hopes of the poor, our faith rooted in the reality of the Lordship of Jesus Christ, we will rediscover our voice, reestablish our belief that the world can be changed, that God's kingdom will come, and that God's will shall be done, on earth, as it is in heaven. And we will discover too, that which has so gripped the imagination of Piet Meiring as he worked with the TRC, namely the wondrous works of "the God of surprises".

\section{Consulted literature}

Bell, T \& Ntsebeza, D B 2001. Unfinished Business, South Africa, Apartheid \& Truth. Cape Town: Red Works.

Boesak, A A 2005. The Tenderness of Conscience, African Renaissance and the Spirituality of Politics. Stellenbosch: Sun Press.

Calvin J, 1950. Commentaries on the four last books of Moses in the form of a harmony: [Exodus, Leviticus, Deuteronomy, Numbers] by John Calvin; translated from the original Latin, and compared with the French edition; with annotations, etc by Charles William Bingham, Grand Rapids: Eerdmans.

De Gruchy, J 2002. Reconciliation: Restoring Justice. Cape Town: David Philip.

De Lange, J 2000. The historical and legal origins of the South African Truth and Reconciliation Commiccion in Villa-Vicencio, C \& Verwoerd, W (eds), Looking Back, Reaching Forward, Cape Town: UCT Press, 14-31

Graybill, L S 2002. Truth and Reconciliation in South Africa. Boulder Co \& London: Lynne Renier Publishers.

Gerwel, J 2000. National reconciliation in Villa-Vicencio, C \& Verwoerd, W (eds), Looking Back, Reaching Forward, Cape Town: UCT Press, 277-286.

Makgoba, M W, Shope T \& Mazwai, T 1999. African Renaissance, The New Struggle. Cape Town: Tafelberg \& Mafube.

Mamdani, M 1996. Reconciliation without Justice, Southern African Review of Books, Issue 46, November/December 1996.

Mandaza, I 1999. Reconciliation and Social Justice in Southern Africa, in Makgoba, M W, Shope T \& Mazwai, T 1999. African Renaissance, The New Struggle. Cape Town: Tafelberg \& Mafube, 77-100.

Meiring, P 2000. Chronicle of the Truth and Reconciliation Commission. Bloemfontein: Carpe Diem.

Ramphele, M 2008. Laying Ghosts to Rest, Dilemmas of the Transformation in South Africa. Cape Town: Tafelberg. 
Tutu, D 1999. No Future Without Forgiveness. Johannesburg: Rider.

Terreblance, S 2000. Dealing with Systematic Economic Injustice, in VillaVicencio, C \& Verwoerd, W (eds), Looking Back, Reaching Forward. Cape Town: UCT Press, 265-276.

Verwoerd, W 1998. Forgiving the Torturer but not the Torture, Sunday Independent, December 14, 1998.

Villa-Vicencio, C \& Verwoerd, W 2000. Looking Back, Reaching Forward. Cape Town: UCT Press and London: Zed Books.

Wiersinga, H 1971. De Verzoening in de Theologische Discussie. Kampen: Kok.

Wolterstorff, N 1999, the Contours of Justice, An Ancient Call for Shalom, in Lisa Barnes Lampman (ed), God and the Victim: Theological Reflections on Evil, Victimization, Justice and Forgiveness. Grand Rapids: Eerdmans, 107130. 